\title{
Effect of Age on Liver Function in Patients Undergoing Partial Hepatectomy
}

\author{
T.M. Lodewick ${ }^{a, c, d}$ P.H. Alizai ${ }^{a, c}$ R.M. van Dam ${ }^{c, d}$ A.A.J. Roeth ${ }^{a, c}$ \\ M. Schmeding ${ }^{a, c}$ C. Heidenhain ${ }^{a, c}$ A. Andert ${ }^{a, c} \quad$ N. Gassler ${ }^{b}$ \\ C.H.C. Dejong ${ }^{c-e}$ U.P. Neumann ${ }^{a, c, d}$
}

a Department of General, Visceral and Transplantation Surgery, RWTH University Hospital Aachen, and ${ }^{\mathrm{b}}$ Institute of Pathology, RWTH Aachen University, Aachen, Germany; ' $E$ uregional HPB Collaboration Aachen-Maastricht, Aachen-Maastricht, ${ }^{\mathrm{d}}$ Department of Surgery, Maastricht University Medical Centre and Nutrim School for Nutrition, Toxicology and Metabolism, and ${ }^{\mathrm{E}} \mathrm{GROW}$ School for Oncology and Developmental Biology, Maastricht University, Maastricht, The Netherlands

\section{Keywords}

Elderly · Age · LiMAx · Postresectional liver failure · Liver function

\begin{abstract}
Background: Postresectional liver failure is the most frequent cause of fatal outcome following liver surgery. Diminished preoperative liver function in the elderly might contribute to this. Therefore, the aim of the present study was to evaluate preoperative liver function in patients $<60$ or $>70$ years of age scheduled for liver resection. Methods: All consecutive patients aged $<60$ or $>70$ years who are about to undergo elective liver surgery between 2011 and 2013 and underwent the methacetin breath liver function test (LiMAx) preoperatively were included. Histologic assessment of the resected liver gave insight into background liver disease. Correlation between age and liver function was calculated with Pearson's test. Results: Fifty-nine patients were included, 31 were aged $<60$ and 28 were aged $>70$ years. General patient characteristics and liver function LiMAx values (340
\end{abstract}

\begin{tabular}{ll}
\hline KARGER & $\begin{array}{l}\text { ( } 2017 \text { The Author(s) } \\
\text { Published by S. Karger AG, Basel } \\
0253-4886 / 16 / 0343-0233 \$ 39.50 / 0\end{array}$ \\
E-Mail karger@karger.com & Open access \\
www.karger.com/dsu & This article is licensed under the Creative Commons Attribution- \\
& $\begin{array}{l}\text { NonCommercial-NoDerivatives 4.0 International License (CC BY- } \\
\text { NC-ND) (http://www.karger.com/Services/OpenAccessLicense). } \\
\text { Usage and distribution for commercial purposes as well as any dis- } \\
\text { tribution of modified material requires written permission. }\end{array}$
\end{tabular}

(137-594) vs. 349 (191-530) $\mu \mathrm{g} / \mathrm{kg} / \mathrm{h}, \mathrm{p}=0.699)$ were not significantly different between patients aged $<60$ and $>70$ years. Moreover, no correlation between age and preoperative liver function LiMAx values was found $(R=0.04, p=$ 0.810). Conclusion: Liver function did not seem to differ between younger and older patients.

\section{(C) 2017 The Author(s)}

Published by S. Karger AG, Basel

\section{Introduction}

Liver resection is associated with considerable morbidity rates. The perioperative mortality rate is usually below $5 \%$ [1-4] and about 10\% in patients undergoing complex major liver resections [5-8]. One of the main reasons for adverse postoperative outcome after hepatectomy is postresectional liver failure (PLF). A remnant liver that either is too small or has inadequate function is prone to this severe and often lethal complication. At least $25-30 \%$ of the total liver volume needs to be preserved to prevent PLF $[9,10]$ in otherwise healthy livers. For a safe liver resection

Toine M. Lodewick, MD

Department of Surgery, Maastricht University Medical Centre P. Debyelaan 25, 6229 HX Maastricht, PO Box 5800 NL-6202 AZ Maastricht (The Netherlands) E-Mail t.lodewick@ maastrichtuniversity.nl 
in patients with liver steatosis or fibrosis, it is already known that a larger remnant liver needs to be preserved.

The LiMAx methacetin liver function breath test is currently considered one of the most accurate liver function tests [11]. A remnant LiMAx value of over $100 \mu \mathrm{g} /$ $\mathrm{kg} / \mathrm{h}$ is considered sufficient to prevent PLF [11]. Despite improvements in preoperative assessment of patients undergoing major liver resections, PLF still occurs in up to $5 \%$ of all patients and remains difficult to predict [12].

In many centers, old age is a relative contraindication for resection of malignancies located in the liver because several multicenter nationwide studies have indicated that major morbidity and mortality rates have increased in the elderly $[13,14]$. Hypothetically, elderly patients might have diminished liver function already preoperatively and this might explain or contribute to the higher mortality in this patient group. Preservation of a larger remnant might therefore be necessary for the elderly.

The aim of the present study was to evaluate preoperative liver function in patients undergoing partial hepatectomy $<60$ or $>70$ years of age.

\section{Material and Methods}

\section{Patients}

This study was conducted according to the revised version of the Declaration of Helsinki (October 2008, Seoul). In this retrospective study, all consecutive patients $<60$ or $>70$ years of age, undergoing elective liver surgery between January 2011 and September 2013, and who underwent a LiMAx $[15,11]$ methacetin liver function breath test prior to surgery at the RWTH University Hospital Aachen, were included. The decision for LiMAx evaluation was based on clinical indications (such as resection of 4 or more liver segments and known or suspected fibrosis or cirrhosis) and was made by the responsible surgeons. Patients who underwent portal vein embolization (PVE) prior to resection were only included when a pre-PVE LiMAx-test was performed. This pre-PVE test was then used as initial preoperative value.

\section{Methods}

Liver Function Test

The LiMAx test was used to assess hepatocyte specific metabolic function. This test is based on the metabolization of ${ }^{13} \mathrm{C}$-labelled methacetin (Euriso-top, Saint-Aubin Cedex, France) by the cytochrome P450 1A2 enzyme in the liver $[15,11]$. After intravenous injection, ${ }^{13} \mathrm{C}$-labelled methacetin is instantly metabolized and the ratio between exhaled ${ }^{13} \mathrm{CO}_{2}$ and normal non-enriched background ${ }^{12} \mathrm{CO}_{2}$ is registered over a period of $60 \mathrm{~min}$ [11]. In patients undergoing resection of large volumes of the liver with limited LiMAx values, liver volumetry was performed to predict the future remnant LiMAx liver function value. A future remnant LiMAx liver function of $100 \mu / \mathrm{kg} / \mathrm{h}$ was considered sufficient to prevent PLF [15]. If the surgical strategy would indicate leaving behind an insufficient liver remnant, a PVE or an ALPPS [16, 17] (associating liver partition and portal vein ligation for staged hepatectomy) procedure was performed to enlarge the volume and function of the future liver remnant.

\section{Outcome Parameters}

Standard demographics, therapeutic, operative and outcome data were collected and subsequently analysed. Postoperative morbidity was graded according to the Dindo-Clavien classification [18]. Complications with a grade $\geq 3$ a were considered major complications. As the incidence of many liver surgery specific complications is low, differences between groups are difficult to analyse. Therefore, postoperative morbidity was also scored according to a liver-specific composite end point (LSCEP) consisting of ascites, PRLF, bile leakage, intra-abdominal hemorrhage, intra-abdominal abscess and operative mortality [19]. Morbidity and mortality rates are provided as 90-day morbidity and 90-day mortality rates, including all complications that were not present at discharge, but which led to readmissions or death within 90 days.

\section{Liver Resection}

Liver resection was performed as described previously [20]. After mobilization of the liver, intraoperative ultrasound provided insight into the feasibility of the preoperatively planned surgical procedure. To prevent excessive blood loss, central venous pressure was maintained below $5 \mathrm{~cm} \mathrm{H}_{2} \mathrm{O}$ during transection. Hilar inflow occlusion (Pringle maneuver) was performed for a maximum of $30 \mathrm{~min}$ in case of increased bleeding. If tumors invaded main bile structures and were still considered resectable, then a biliary tract resection and Roux-en-Y hepaticojejunostomy was performed. Need for vascular and portal vein resections and potential reconstruction were not considered to be the criteria for irresectability but were performed when needed. All liver resections were classified in accordance with the IHPBA Brisbane nomenclature [21].

\section{Histopathology}

One pathologist (N.G.) performed all pathologic examinations. Fibrosis of background liver tissue was classified using the Metavir score which among others consists of a 5-point fibrosis scale [22]. The degree of non-alcoholic steatohepatitis (NASH) was analyzed using the NASH Scoring system (NAS score) [23]. Finally, sinusoidal dilatation was scored on a 4-point scale as a measure of sinusoidal obstruction syndrome [24].

\section{Statistical Analysis}

Data were analyzed with SPSS version 20.0 (SPSS Inc., Chicago, Ill., USA) and Prism 5.0 for Macintosh (GraphPad software, Inc., San Diego, Calif., USA). Data were expressed as median (range). Chi-square tests were used to analyze categorical data while continuous data were analyzed with Mann-Whitney U tests. A level of $\mathrm{p}<0.05$ was considered statistically significant. Correlation between age and liver function was performed in patients with relatively healthy livers, that is, livers without cirrhosis (Metavir fibrosis scale stage 4 [22]), NASH (NAS score $\geq 5$ [23]) or severe sinusoidal dilatation (sinusoidal dilatation score $=3$ [24]). Patients without pathologic examination of liver tissue were excluded for correlation analysis. Correlation between age and liver function was calculated with Pearson's test. The resulting regression line was described as a linear equation and the correlation coefficient (r) was calculated.
Lodewick et al. 
Table 1. Clinical characteristics

\begin{tabular}{|c|c|c|c|c|}
\hline Variables & $\begin{array}{l}\text { All patients } \\
(\mathrm{n}=59)\end{array}$ & $\begin{array}{l}\text { Age }<60 \text { years } \\
(\mathrm{n}=31)\end{array}$ & $\begin{array}{l}\text { Age }>70 \text { years } \\
(\mathrm{n}=28)\end{array}$ & $\mathrm{p}$ value \\
\hline \multicolumn{5}{|l|}{ Patient characteristics } \\
\hline Age, years, median (range) & $58(28-85)$ & $54(28-58)$ & $74(70-85)$ & $<0.001$ \\
\hline Gender, female & $21(35.6)$ & $10(32)$ & $11(39)$ & 0.573 \\
\hline Height, m, median (range) & $1.72(1.55-1.93)$ & $1.76(1.60-1.93)$ & $1.69(1.55-1.89)$ & 0.003 \\
\hline Weight, kg, median (range) & $79(47-109)$ & $80(50-109)$ & $77(47-104)$ & 0.627 \\
\hline Body mass index, $\mathrm{kg} / \mathrm{m}^{2}$, median (range) & $25.0(18.7-37.7)$ & $24.5(18.7-37.7)$ & $25.8(19.2-36.0)$ & 0.324 \\
\hline \multicolumn{5}{|l|}{ ASA classification } \\
\hline ASA 1 & $5(8.5)$ & $4(13)$ & $1(4)$ & 0.199 \\
\hline ASA 2 & $26(44.1)$ & $13(42)$ & $13(46)$ & 0.728 \\
\hline ASA 3 or 4 & $28(47.5)$ & $14(45)$ & $14(50)$ & 0.710 \\
\hline Portal vein embolisation & $21(35.6)$ & $11(35)$ & $10(36)$ & 0.985 \\
\hline \multicolumn{5}{|l|}{ Preoperative liver function } \\
\hline LiMAx liver function, $\mu / \mathrm{kg} / \mathrm{h}$, median (range) & $340(137-594)$ & $340(137-594)$ & $349(191-530)$ & 0.699 \\
\hline \multicolumn{5}{|l|}{ Preoperative laboratory details, median (range) } \\
\hline INR, ratio & $1.03(0.87-1.32)$ & $1.01(0.88-1.30)$ & $1.05(0.87-1.32)$ & 0.485 \\
\hline Bilirubin, mg/dl & $0.6(0.2-3.7)$ & $0.7(0.2-2.5)$ & $0.6(0.2-3.7)$ & 0.427 \\
\hline \multicolumn{5}{|l|}{ Background liver } \\
\hline Metavir score, median (range) & $1(0-6)$ & $2(0-6)$ & $1(0-6)$ & 0.192 \\
\hline NAS score, median (range) & $1(0-5)$ & $1(0-4)$ & $1(0-5)$ & 0.236 \\
\hline Sinusoidal dilatation score, median (range) & $0(0-3)$ & $0(0-3)$ & $0(0-2)$ & 0.228 \\
\hline \multicolumn{5}{|l|}{ Percentage with severe back-ground liver disease } \\
\hline (cirrhosis, NASH or sinusoidal dilatation grade 3 ) & 10.0 & 12 & 8 & 0.637 \\
\hline \multicolumn{5}{|l|}{ Indication } \\
\hline Colorectal liver metastases & $17(28.8)$ & $8(26)$ & $9(32)$ & 0.592 \\
\hline Other metastases & $5(8.5)$ & $4(13)$ & $1(4)$ & 0.199 \\
\hline Hepatocellular carcinoma & $7(11.9)$ & $3(10)$ & $4(14)$ & 0.585 \\
\hline Cholangiocarcinoma & $25(42.4)$ & $13(42)$ & $12(43)$ & 0.943 \\
\hline Benign lesions & $3(5.1)$ & $2(6)$ & $1(4)$ & 0.615 \\
\hline Other & $2(3.4)$ & $1(3)$ & $1(4)$ & - \\
\hline \multicolumn{5}{|l|}{ Laesion, median (range) } \\
\hline Size largest lesion, $\mathrm{cm}$ & $5(0-16)$ & $5(0-16)$ & $6(1-12)$ & 0.215 \\
\hline Number of lesions & $1(0-6)$ & $1(0-5)$ & $1(1-6)$ & 0.801 \\
\hline \multicolumn{5}{|l|}{ Chemotherapy } \\
\hline Preoperative chemotherapy & $12(20.3)$ & $7(23)$ & $5(18)$ & 0.653 \\
\hline
\end{tabular}

\section{Results}

\section{Patients}

A total of 59 patients were included in the present study. Thirty-one patients were $<60$ and 28 were $>70$ years of age. General patient characteristics were comparable (table 1). PVE, to enlarge the future remnant liver volume before resection, was performed in 21 patients (35.6\%). Most patients who were included underwent resection for cholangiocarcinoma $(\mathrm{n}=25,42.4 \%)$, colorectal liver metastases $(\mathrm{n}=17,28.8 \%)$ or hepatocel- lular carcinoma ( $\mathrm{n}=7,11.9 \%)$. No difference in indication between the 2 age groups was observed (table 1).

\section{Liver Function}

Liver function LiMAx values were $340(137-594) \mu \mathrm{g} /$ $\mathrm{kg} / \mathrm{h}$ in patients $<60$ years and $349(191-530) \mu \mathrm{g} / \mathrm{kg} / \mathrm{h}$ in patients $>70$ years $(p=0.699)$. No correlation between age and preoperative liver function LiMAx values was found $(\mathrm{R}=0.04, \mathrm{p}=0.810$; fig. 1$)$. Preoperative INR and bilirubin levels were comparable between the groups (table 1). 


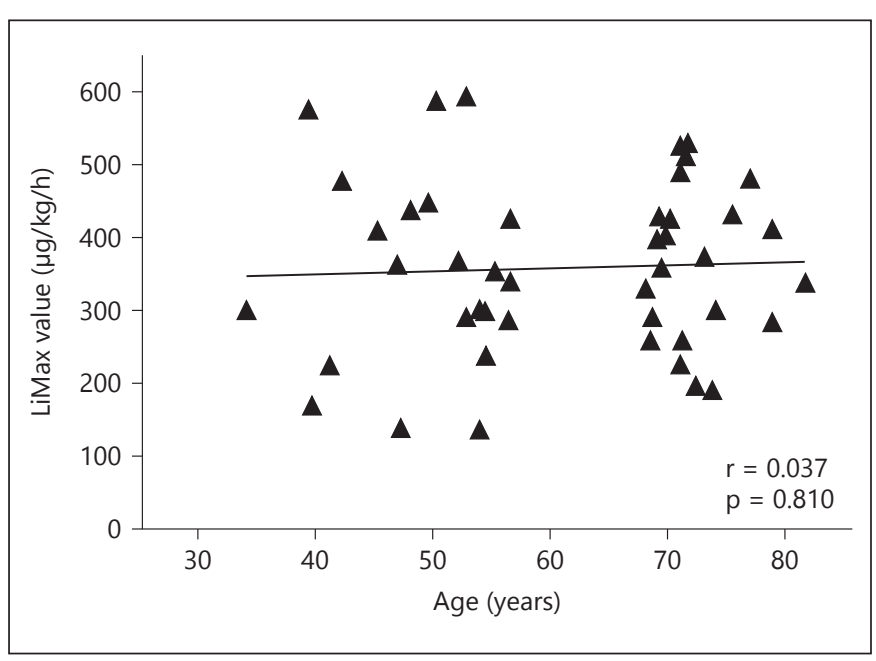

Fig. 1. Correlation graph between LiMAx liver function value and age.

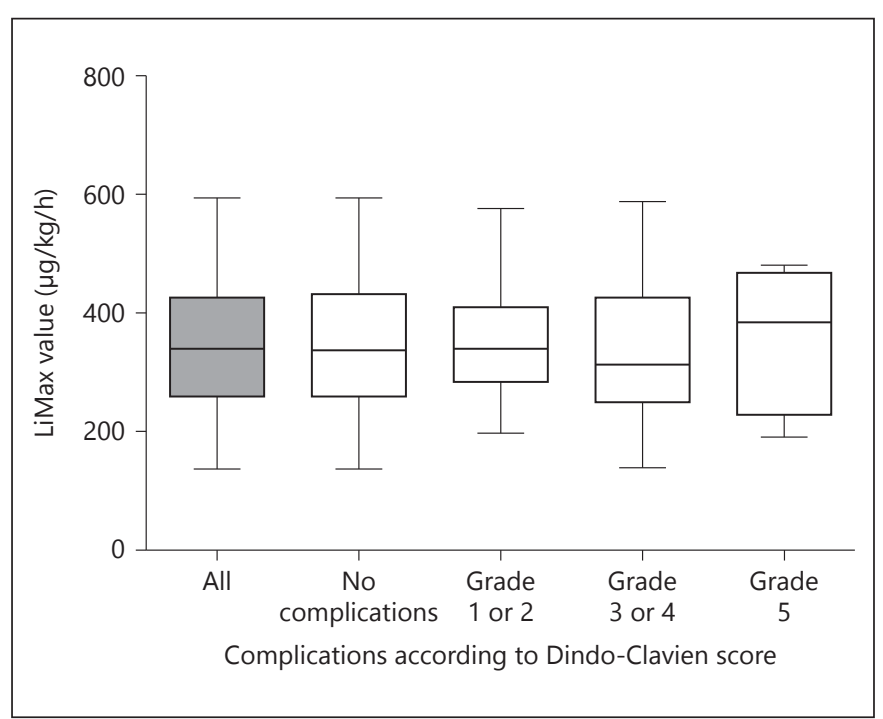

Fig. 2. LiMAx liver function values according to complication grade. In the grey boxplot, all patients included in the present study are depicted. In the white boxplots, patients without complications, with Dindo-Clavien grade 1 or 2, 3 or 4 and 5 are shown, respectively.

Also, LiMAx values were comparable between patients without complications and patients with Dindo-Clavien grade 1 or $2(\mathrm{p}=0.967)$, grade 3 or $4(\mathrm{p}=0.856)$ and grade 5 ( $\mathrm{p}=0.889$; fig. 2 ).

\section{Background Liver}

Histologic evaluation was performed in $84.7 \%(n=50)$ of all patients. The pathologist was unable to retrospectively analyze the background liver tissue in the remain- ing 9 patients due to insufficient amount of background liver tissue. Three (6.0\%) patients had liver cirrhosis. All cirrhotic patients were men and 2 were under the age of 60 years. There were $2(4.0 \%)$ patients with severe sinusoidal dilatation and $1(2.0 \%)$ patient had NASH (NAS score $\geq 5$ ). However, there were no differences in Metavir, NAS and sinusoidal dilation scores between patients $<60$ and $>70$ years. Moreover, presence of severe background disease was comparable in the 2 groups ( $\mathrm{p}=0.637$; table 1).

\section{Liver Resection}

Operative details are depicted in table 2. Twenty-seven (45.8\%) patients underwent an extended left or right hemihepatectomy, 19 (32.2\%) patients underwent a left or right hemihepatectomy and $13(22.0 \%)$ underwent smaller resections in livers with altered parenchyma due to fibrosis or cirrhosis. Surgical strategies were comparable between the 2 groups. However, patients $<60$ years more often underwent additional procedures, that is, ALPPS $[17,16]$, pylorus-preserving pancreatico-duodenectomy (PPPD) and vascular or biliary resections and/ or reconstructions (22 (37.3\%) vs. $7(11.9 \%), \mathrm{p}=0.002)$. Consequently, the duration of surgery was significantly longer in patients $<60$ years than in the elderly $(315$ ( 120 $510)$ vs. $253(113-444) \mathrm{min}, \mathrm{p}=0.012)$. An oncological complete resection without microscopic residual tumor was reached in $89.3 \%$ of patients $<60$ and $88.5 \%$ of patients $>70$ years $(\mathrm{p}=0.923)$.

\section{Length of Hospitalization}

Postoperative nights spent in hospital were 17 (2-86) vs. $12(5-81)$ nights in patients $<60$ and $>70$ years, respectively $(\mathrm{p}=0.171)$.

\section{Mortality}

One (3.2\%) patient $<60$ years of age suddenly died from cardiopulmonary failure due to a coronary stenosis after he had recovered completely from surgery. In the group of patients $>70$ years, $3(10.7 \%)$ patients died, 2 of septic complications and 1 of PLF and bowel ischemia. The difference in mortality did not reach statistical significance $(\mathrm{p}=0.253$; table 3$)$.

\section{Morbidity}

Twenty-six (83.9\%) patients aged $<60$ years and 18 (64.3\%) patients aged $>70$ years developed complications $(\mathrm{p}=0.084)$. Major complication rates did not differ statistically between the groups, 58.1 vs. $39.3 \%$ in patients $<60$ and $>70$ years, respectively $(\mathrm{p}=0.150)$. Thirty-two
Lodewick et al. 
Table 2. Comparison of surgical strategies, pathological details and length of hospital stay

\begin{tabular}{|c|c|c|c|c|}
\hline Variables & $\begin{array}{l}\text { All patients } \\
(\mathrm{n}=59)\end{array}$ & $\begin{array}{l}\text { Age }<60 \text { years } \\
(\mathrm{n}=31)\end{array}$ & $\begin{array}{l}\text { Age }>70 \text { years } \\
(\mathrm{n}=28)\end{array}$ & $\mathrm{p}$ value \\
\hline \multicolumn{5}{|l|}{ Resection } \\
\hline Right hemihepatectomy & $17(28.8)$ & $9(29.0)$ & $8(28.6)$ & 0.969 \\
\hline Left hemihepatectomy & $2(3.4)$ & $0(0.0)$ & $2(7.1)$ & 0.130 \\
\hline Right extended hemihepatectomy & $25(42.4)$ & $15(48.4)$ & $10(35.7)$ & 0.325 \\
\hline Left extended hemihepatectomy & $2(3.4)$ & $1(3.2)$ & $1(3.6)$ & - \\
\hline Uni-segmentectomy or multi-metastasectomy & $6(10.2)$ & $4(12.9)$ & $2(7.1)$ & 0.465 \\
\hline Multi-segmentectomy & $7(11.9)$ & $2(6.5)$ & $5(17.9)$ & 0.176 \\
\hline \multicolumn{5}{|l|}{ Operative details } \\
\hline Estimated blood loss, ml, median (range) & $1,000(100-5,500)$ & $600(100-5,500)$ & $1,350(300-2,500)$ & 0.480 \\
\hline Duration of operation, min, median (range) & $284(113-510)$ & $315(120-510)$ & $253(113-444)$ & 0.012 \\
\hline Percentage with Pringle maneuvre & 10.5 & 6.5 & 15.4 & 0.274 \\
\hline ALPPS procedure & $6(10.2)$ & $4(12.9)$ & $2(7.1)$ & 0.465 \\
\hline Combined with PPPD & $2(3.4)$ & $2(6.5)$ & $0(0.0)$ & - \\
\hline Additional vascular or biliary procedure & $21(35.6)$ & $16(51.6)$ & $5(17.9)$ & 0.007 \\
\hline \multicolumn{5}{|l|}{ Postoperative laboratory details, median (range) } \\
\hline INR on POD 5 , ratio & $1.11(0.94-1.45)$ & $1.13(0.94-1.45)$ & $1.09(1.00-1.38)$ & 0.599 \\
\hline Bilirubin POD 5, mg/dl & $0.8(0.4-5.1)$ & $0.8(0.5-5.1)$ & $0.7(0.4-3.7)$ & 0.134 \\
\hline Peak bilirubin, $\mathrm{mg} / \mathrm{dl}$ & $1.7(0.5-23.1)$ & $1.8(0.9-23.1)$ & $1.5(0.5-10.2)$ & 0.060 \\
\hline \multicolumn{5}{|l|}{ Pathology } \\
\hline Percentage with $\mathrm{R} 0$ resections & 88.9 & 89.3 & 88.5 & 0.923 \\
\hline Percentage with $\mathrm{R} 1$ resections & 11.1 & 10.7 & 11.5 & 0.923 \\
\hline \multicolumn{5}{|l|}{ Length of hospital stay, days, median (range) } \\
\hline Intensive care unit & $1(0-38$ & $1(1-31)$ & $1(0-38)$ & 0.585 \\
\hline Postoperative nights & $15(2-86)$ & $17(2-86)$ & $12(5-81)$ & 0.171 \\
\hline LOS & $17(6-112)$ & $18(7-87)$ & $15(6-112)$ & 0.174 \\
\hline \multicolumn{5}{|l|}{ Readmissions } \\
\hline \multirow{2}{*}{$\begin{array}{l}\text { Number of patients readmitted } \\
\text { Postoperative nights including readmission, } \\
\text { days, median (range) }\end{array}$} & $15(25.4)$ & $11(35.5)$ & $4(14.3)$ & 0.062 \\
\hline & $15(5-90)$ & $19(5-90)$ & $13(5-81)$ & 0.106 \\
\hline
\end{tabular}

(54.2\%) patients developed one or more items of the LSCEP. Thus, 19 (61.3\%) patients $<60$ years and 13 (46.4\%) patients $>70$ years met at least one of the criteria for the LSCEP ( $p=0.253$ ). Detailed comparison of all complications is depicted in table 3.

\section{Discussion}

Large nationwide studies have indicated that morbidity and mortality rates have increased in elderly patients undergoing liver resection $[13,14]$. As this might be because of preoperatively diminished liver function, the present study aimed at evaluating the effect of age on preoperative liver function in patients scheduled for partial hepatectomy. Preoperative liver function as- sessed with the LiMAx test was not significantly different between patients $<60$ and $>70$ years of age. Moreover, no correlation between age and liver function was found.

As the present study has shown that the preoperative LiMAx liver function values were not significantly different between patients $<60$ and $>70$ years of age, the hypothesis that elderly patients show higher mortality rates due to diminished preoperative liver function and predisposition for PLF seems difficult to sustain. However, it could still be that the liver's ability to regenerate after partial resection is diminished causing increased risk of PLF and increased mortality after hepatectomy $[13,14]$. The latter is also supported by a recent study of Shirabe et al. [25] showing that age was inversely correlated with liver regeneration in the first week after hepatectomy. 
Table 3. Complications

\begin{tabular}{|c|c|c|c|c|}
\hline Variables & $\begin{array}{l}\text { All patients } \\
(\mathrm{n}=59)\end{array}$ & $\begin{array}{l}\text { Age }<60 \text { years } \\
(n=31)\end{array}$ & $\begin{array}{l}\text { Age }>70 \text { years } \\
(n=28)\end{array}$ & $\mathrm{p}$ value \\
\hline \multicolumn{5}{|l|}{ Grading of complications } \\
\hline Number of patients with complications & $44(74.6)$ & $26(83.9)$ & $18(64.3)$ & 0.084 \\
\hline Minor complications present & $15(25.4)$ & $8(25.8)$ & $7(25.0)$ & 0.943 \\
\hline Clavien-Dindo grade 1 & $1(1.7)$ & $1(3.2)$ & $0(0.0)$ & - \\
\hline Clavien-Dindo grade 2 & $14(23.7)$ & $7(22.6)$ & $7(25.0)$ & 0.827 \\
\hline Major complications present & $29(49.2)$ & $18(58.1)$ & $11(39.3)$ & 0.150 \\
\hline Clavien-Dindo grade $3 a$ & $17(28.8)$ & $12(38.7)$ & $5(17.9)$ & 0.077 \\
\hline Clavien-Dindo grade $3 \mathrm{~b}$ & $5(8.5)$ & $3(9.7)$ & $2(7.1)$ & 0.727 \\
\hline Clavien-Dindo grade $4 \mathrm{a}$ & $2(3.4)$ & $1(3.2)$ & $1(3.6)$ & - \\
\hline Clavien-Dindo grade $4 \mathrm{~b}$ & $1(1.7)$ & $1(3.2)$ & $0(0.0)$ & - \\
\hline Clavien-Dindo grade 5 & $4(6.8)$ & $1(3.2)$ & $3(10.7)$ & 0.253 \\
\hline \multicolumn{5}{|l|}{ LSCEP } \\
\hline Number of patients with 1 or more items of LSCEP & $32(54.2)$ & $19(61.3)$ & $13(46.4)$ & 0.253 \\
\hline Ascites & $8(13.6)$ & $5(16.1)$ & $3(10.7)$ & 0.544 \\
\hline Postresectional liver failure & $1(1.7)$ & $0(0.0)$ & $1(3.6)$ & - \\
\hline Bile leak & $11(18.6)$ & $7(22.6)$ & $4(14.3)$ & 0.414 \\
\hline Intra-abdominal hemorrhage & $7(11.9)$ & $4(12.9)$ & $3(10.7)$ & 0.795 \\
\hline Intra-abdominal abscess & $16(27.1)$ & $9(29.0)$ & $7(25.0)$ & 0.728 \\
\hline Mortality & $4(6.8)$ & $1(3.2)$ & $3(10.7)$ & 0.253 \\
\hline \multicolumn{5}{|l|}{ Other liver-related complications } \\
\hline Hepatic encephalopathy & $1(1.7)$ & $1(3.2)$ & $0(0.0)$ & - \\
\hline Cholangitis & $3(5.1)$ & $3(9.7)$ & $0(0.0)$ & 0.091 \\
\hline Portal vein thrombosis & $1(1.7)$ & $1(3.2)$ & $0(0.0)$ & - \\
\hline \multicolumn{5}{|l|}{ Other complications } \\
\hline Sepsis & $4(6.8)$ & $2(6.5)$ & $2(7.1)$ & 0.916 \\
\hline Cardiovascular & $6(10.2)$ & $2(6.5)$ & $4(14.3)$ & 0.320 \\
\hline Pulmonary & $13(22.0)$ & $7(22.6)$ & $6(21.4)$ & 0.915 \\
\hline Renal & $3(5.1)$ & $1(3.2)$ & $2(7.1)$ & 0.494 \\
\hline Gastrointestinal & $15(25.4)$ & $9(29.0)$ & $6(21.4)$ & 0.503 \\
\hline Dermatologic & $2(3.4)$ & $0(0.0)$ & $2(7.1)$ & - \\
\hline Wound infection & $4(6.8)$ & $1(3.2)$ & $3(10.7)$ & 0.253 \\
\hline Fascial dehiscence & $2(3.4)$ & $1(3.2)$ & $1(3.6)$ & - \\
\hline
\end{tabular}

Comparing morbidity between patients $<60$ and $>70$ years of age in the present study was not really appropriate as the extent of surgery (i.e., ALPPS strategy, additional PPPD, additional vascular or biliary procedures) differed between the groups. Although this resulted in fewer complications in the elderly, the mortality rate, though not significantly, still tended to be increased in this group. Tzeng et al. [13] already concluded in a large multicenter study on predictors for morbidity and mortality in elderly that if elderly patients develop severe complications, the chance of fatal outcome is increased due to diminished physiologic reserve. The data in the present study seem in line with that conclusion.
The whole cohort mortality rate in the present study $(6.8 \%)$ is fairly high when compared with other studies looking at the overall population with predominantly plain resections [1-4]. All patients included in the present study however were operated in a tertiary referral center and underwent preoperative LiMAx testing, which is done mainly in case of large resections; therefore, a selection bias was present. Almost $80 \%$ of all patients underwent major hepatectomy (resection of 3 or more segments) and almost half (49.1\%) of all patients underwent additional procedures. When these additional procedures are taken into account, the overall mortality rate of $6.8 \%$ and mortality rate in elderly of $10.7 \%$ seem reasonable and are comparable with other studies evaluating out- 
come after extensive liver resection (5.4-25.0\%) [5-8]. Also the high complication rate of $74.6 \%$ in the present study is in line with other studies looking into large and complex liver resection that showed morbidity rates of up to $76 \%$ [26].

Studies evaluating the safety of liver surgery do not use a standard cutoff value to define the elderly. Most studies define the 'elderly' as patients $>70[27,28]$ or $75[29]$, while others use 65 [30] or even 80 [31] years of age. When the elderly are compared with younger patients, practically all studies choose to include all patients above and under a certain age (e.g., comparing patients $>75$ with patients $<75$ years) $[9,13,27-29,31]$. Borderline elderly in studies conducted according to such definitions might well affect the clarity of the results and messages as slight differences in age may put patients in different cohorts. The design of the present study therefore left a gap of 10 years between the elderly population and the relatively young population to avoid 'cross contamination' and hence enhance possible differences in preoperative liver function.

This study included patients in a small period of time in which perioperative care has not changed and this may be considered a strong point of this study. To date, there is no gold standard for evaluation of the liver function. However, the use of the LiMAx methacetin breath test seems a relative strong point of the study as conventional liver function analysis using blood parameters or scoring systems (i.e., the Model of End-Stage Liver Disease score and the Child-Pugh score) have shown to be insufficient for reliable prediction of the remnant liver function after partial hepatectomy [32-34]. Multiple dynamic tests, such as the Indocyanin Green clearance or the LiMAx methacetin breath test, have been proposed and seem to provide more information on liver function [15, 35]. Moreover, the LiMAx test is believed to be able to validly determine liver function [15]. The high complication rate underlines the adequate complication registration in RWTH University Hospital Aachen. Many studies underestimate mortality and morbidity rates as they use 30, 60 days or in hospital morbidity and mortality, which underestimate the actual numbers. Complications leading to readmissions are therefore often not reported. The present study used 90-day morbidity and mortality, and consequently also included all complications when patients were readmitted. The small sample size, however, is a downside as some parameters might have reached significance if the sample size would have been larger. Although no significant differences between the groups were found on background liver disease and in-

Effects of Age on Liver Function dication for surgery, the heterogeneity of the study population and therefore of the background liver disease is a weakening factor possibly influencing the results. This probably also explains the large differences in LiMAx values between patients (fig. 1). Larger studies evaluating preoperative liver function and postoperative functional regeneration in a homogenous population of patients $<60$ and $>70$ years of age are needed to clarify the effect of age on regeneration capacity and to investigate whether diminished regeneration capacity is the actual cause of increased morbidity and mortality in elderly patients. As in recent years the indications for resection have been broadened triggered by continuous improvements in surgical technique and perioperative care $[3,36,37]$, the effect of age on morbidity and mortality might also possibly have changed. New larger studies, in modern day cohorts, are therefore needed to investigate the effect of age on complications as it might be that old age should no longer be considered a relative contraindication for resection.

In conclusion, elderly patients scheduled for liver resection do not seem to have impaired preoperative liver function. Thus, the present study could not confirm a link between age and diminished liver function that might explain any increased morbidity and mortality rates in the elderly undergoing liver resection. Mortality rates, though not significant, tended to be increased in the elderly.

\section{Statement of Ethics}

This study did not require informed consent nor review/approval by the appropriate ethics committee.

\section{Disclosure Statement}

The authors have no conflicts of interest to disclose.

References $\quad$ Cescon M, Vetrone G, Grazi GL, Ramacciato
G, Ercolani G, Ravaioli M, Del Gaudio M,
Pinna AD: Trends in perioperative outcome
after hepatic resection: analysis of 1500 con-
secutive unselected cases over 20 years. Ann
Surg 2009;249:995-1002.
2 Jarnagin WR, Gonen M, Fong Y, DeMatteo
RP, Ben-Porat L, Little S, Corvera C, Weber S,
Blumgart LH: Improvement in perioperative
outcome after hepatic resection: analysis of
1,803 consecutive cases over the past decade.
Ann Surg 2002;236:397-406; discussion 406-
407.


3 de Haas RJ, Wicherts DA, Andreani P, Pascal G, Saliba F, Ichai P, Adam R, Castaing D, Azoulay D: Impact of expanding criteria for resectability of colorectal metastases on short- and long-term outcomes after hepatic resection. Ann Surg 2011;253:10691079.

-4 Virani S, Michaelson JS, Hutter MM, Lancaster RT, Warshaw AL, Henderson WG, Khuri SF, Tanabe KK: Morbidity and mortality after liver resection: results of the patient safety in surgery study. J Am Coll Surg 2007;204:1284-1292.

5 Gerhards MF, van Gulik TM, de Wit LT, Obertop H, Gouma DJ: Evaluation of morbidity and mortality after resection for hilar cholangiocarcinoma - a single center experience. Surgery 2000;127:395-404.

6 DeOliveira ML, Cunningham SC, Cameron JL, Kamangar F, Winter JM, Lillemoe KD, Choti MA, Yeo CJ, Schulick RD: Cholangiocarcinoma: thirty-one-year experience with 564 patients at a single institution. Ann Surg 2007;245:755-762.

-7 Nagino M, Ebata T, Yokoyama Y, Igami T, Sugawara G, Takahashi Y, Nimura Y: Evolution of surgical treatment for perihilar cholangiocarcinoma: a single-center 34-year review of 574 consecutive resections. Ann Surg 2013;258:129-140.

$>8$ Nuzzo G, Giuliante F, Ardito F, Giovannini I, Aldrighetti L, Belli G, Bresadola F, Calise F, Dalla Valle R, D'Amico DF, Gennari L, Giulini SM, Guglielmi A, Jovine E, Pellicci R, Pernthaler H, Pinna AD, Puleo S, Torzilli G, Capussotti L; Italian Chapter of the International Hepato-Pancreato-Biliary Association, Cillo U, Ercolani G, Ferrucci M, Mastrangelo L, Portolani N, Pulitano C, Ribero D, Ruzzenente A, Scuderi V, Federico B: Improvement in perioperative and long-term outcome after surgical treatment of hilar cholangiocarcinoma: results of an Italian multicenter analysis of 440 patients. Arch Surg 2012;147:26-34.

-9 Ferrero A, Vigano L, Polastri R, Muratore A, Eminefendic H, Regge D, Capussotti L: Postoperative liver dysfunction and future remnant liver: where is the limit? Results of a prospective study. World J Surg 2007;31:16431651.

10 Schindl MJ, Redhead DN, Fearon KC, Garden OJ, Wigmore SJ: The value of residual liver volume as a predictor of hepatic dysfunction and infection after major liver resection. Gut 2005;54:289-296.

11 Stockmann M, Lock JF, Riecke B, Heyne K, Martus P, Fricke M, Lehmann S, Niehues SM, Schwabe M, Lemke AJ, Neuhaus P: Prediction of postoperative outcome after hepatectomy with a new bedside test for maximal liver function capacity. Ann Surg 2009;250:119125.

12 van den Broek MA, Olde Damink SW, Dejong $\mathrm{CH}$, Lang $\mathrm{H}$, Malago M, Jalan R, Saner
FH: Liver failure after partial hepatic resection: definition, pathophysiology, risk factors and treatment. Liver Int 2008;28:767-780.

13 Tzeng CW, Cooper AB, Vauthey JN, Curley SA, Aloia TA: Predictors of morbidity and mortality after hepatectomy in elderly patients: analysis of 7621 NSQIP patients. HPB (Oxford) 2014;16:459-468.

14 Farges O, Goutte N, Bendersky N, Falissard B: Incidence and risks of liver resection: an allinclusive French nationwide study. Ann Surg 2012;256:697-704; discussion 704-705.

15 Stockmann M, Lock JF, Malinowski M, Niehues SM, Seehofer D, Neuhaus P: The LiMAx test: a new liver function test for predicting postoperative outcome in liver surgery. HPB (Oxford) 2010;12:139-146.

-16 Schnitzbauer AA, Lang SA, Goessmann H, Nadalin S, Baumgart J, Farkas SA, FichtnerFeigl S, Lorf T, Goralcyk A, Horbelt R, Kroemer A, Loss M, Rummele P, Scherer MN, Padberg W, Konigsrainer A, Lang H, Obed A, Schlitt HJ: Right portal vein ligation combined with in situ splitting induces rapid left lateral liver lobe hypertrophy enabling 2-staged extended right hepatic resection in small-for-size settings. Ann Surg 2012;255: 405-414.

17 Neumann UP, Dejong CH: Split decision. Br J Surg 2013;100:310-312.

18 Dindo D, Demartines N, Clavien PA: Classification of surgical complications: a new proposal with evaluation in a cohort of 6336 patients and results of a survey. Ann Surg 2004; 240:205-213.

19 van den Broek MA, van Dam RM, van Breukelen GJ, Bemelmans MH, Oussoultzoglou E, Pessaux P, Dejong CH, Freemantle N, Olde Damink SW: Development of a composite endpoint for randomized controlled trials in liver surgery. Br J Surg 2011;98:11381145.

20 Dejong CH, Garden OJ: Neoplasms of the liver; in Advanced Surgical Practice, Majid AA, Kingsnorth A (eds): Greenwich Medical Media, London, 2003, pp 146-156.

21 Strasberg SM: Nomenclature of hepatic anatomy and resections: a review of the Brisbane 2000 system. J Hepatobiliary Pancreat Surg 2005; 12:351-355.

22 Bedossa P, Poynard T: An algorithm for the grading of activity in chronic hepatitis $\mathrm{C}$. The METAVIR Cooperative Study Group. Hepatology 1996;24:289-293.

23 Kleiner DE, Brunt EM, Van Natta M, Behling C, Contos MJ, Cummings OW, Ferrell LD, Liu YC, Torbenson MS, Unalp-Arida A, Yeh M, McCullough AJ, Sanyal AJ. Design and validation of a histological scoring system for nonalcoholic fatty liver disease. Hepatology 2005;41:1313-1321.

24 Rubbia-Brandt L, Audard V, Sartoretti P, Roth AD, Brezault C, Le Charpentier M,
Dousset B, Morel P, Soubrane O, Chaussade $S$, Mentha G, Terris B: Severe hepatic sinusoidal obstruction associated with oxaliplatinbased chemotherapy in patients with metastatic colorectal cancer. Ann Oncol 2004;15: 460-466.

25 Shirabe K, Motomura T, Takeishi K, Morita K, Kayashima H, Taketomi A, Ikegami T, Soejima Y, Yoshizumi T, Maehara Y: Human early liver regeneration after hepatectomy in patients with hepatocellular carcinoma: special reference to age. Scand J Surg 2013;102: 101-105.

26 Serrablo A, Tejedor L: Outcome of surgical resection in Klatskin tumors. World J Gastrointest Oncol 2013;5:147-158.

27 Huang J, Li BK, Chen GH, Li JQ, Zhang YQ, Li GH, Yuan YF: Long-term outcomes and prognostic factors of elderly patients with hepatocellular carcinoma undergoing hepatectomy. J Gastrointest Surg 2009;13:16271635.

28 Menon KV, Al-Mukhtar A, Aldouri A, Prasad RK, Lodge PA, Toogood GJ: Outcomes after major hepatectomy in elderly patients. J Am Coll Surg 2006;203:677-683.

29 Ueno M, Hayami S, Tani M, Kawai M, Hirono $\mathrm{S}$, Yamaue H: Recent trends in hepatectomy for elderly patients with hepatocellular carcinoma. Surg Today 2014;44:1651-1659.

30 Ettorre GM, Sommacale D, Farges O, Sauvanet $A$, Guevara $O$, Belghiti J: Postoperative liver function after elective right hepatectomy in elderly patients. Br J Surg 2001;88:73-76.

31 Yamada S, Shimada M, Miyake H, Utsunomiya T, Morine Y, Imura S, Ikemoto T, Mori H, Hanaoka J, Iwahashi S, Saito Y: Outcome of hepatectomy in super-elderly patients with hepatocellular carcinoma. Hepatol Res 2012; 42:454-458.

32 Schneider PD: Preoperative assessment of liver function. Surg Clin North Am 2004;84: 355-373.

33 Sakka SG: Assessing liver function. Curr Opin Crit Care 2007;13:207-214.

- 34 Schroeder RA, Marroquin CE, Bute BP, Khuri S, Henderson WG, Kuo PC: Predictive indices of morbidity and mortality after liver resection. Ann Surg 2006;243:373-379.

35 Fan ST: Liver functional reserve estimation: state of the art and relevance for local treatments: the Eastern perspective. J Hepatobiliary Pancreat Sci 2010;17:380-384.

36 Pawlik TM, Schulick RD, Choti MA: Expanding criteria for resectability of colorectal liver metastases. Oncologist 2008;13:51-64.

37 van Dam RM, Lodewick TM, van den Broek MA, de Jong MC, Greve JW, Jansen RL, Bemelmans MH, Neumann UP, Olde Damink SW, Dejong CH: Outcomes of extended versus limited indications for patients undergoing a liver resection for colorectal cancer liver metastases. HPB (Oxford) 2014;16:550-559. 